\title{
Morphological Variability of Prosopis africana (Guill., Perrott. Et Rich.) Taub in Benin, West Africa
}

\author{
Houètchégnon Towanou ${ }^{1 *}$, Gbèmavo D. S. J. Charlemagne ${ }^{2}$, Ouinsavi Christine ${ }^{1}$, \\ Sokpon Nestor ${ }^{1}$ \\ ${ }^{1}$ Laboratoire d'Etudes et de Recherches Forestières (LERF), Faculté d'Agronomie, Université de Parakou, \\ Parakou, Bénin \\ ${ }^{2}$ Faculté des Sciences Agronomiques, Université d'Abomey-Calavi, Abomey-Calavi, Bénin \\ Email: ${ }^{*}$ houetchegnon@gmail.com
}

Received 20 February 2015; accepted 26 April 2015; published 30 April 2015

Copyright $\odot 2015$ by authors and Scientific Research Publishing Inc.

This work is licensed under the Creative Commons Attribution International License (CC BY). http://creativecommons.org/licenses/by/4.0/

(c) (7) Open Access

\section{Abstract}

The morphological variability of Prosopis africana in its natural range (which includes three climate zones: Guinean zone, Sudano-Guinean zone and Sudanese zone) of Benin was studied on the basis of forest inventory carried out in three different vegetation types (savannah, fallow and field). The data recorded in 139 plots of $1000 \mathrm{~m}^{2}$ each related to the diameter at breast height $(1.3 \mathrm{~m}$ over the ground level), the bole height, the height to the first branch, crown height, the crown diameter, number of branches on each individual tree. In these plots, 143 sheets were used to determine the length of leaf, the pinna length, leaflets' length, numbers of pinna, the number of leaflets, and the stalk diameter. In addition, 735 cloves were measured to determine the fruit pods' diameter, pod length, the total fruit weight and number of seeds per fruit, the seed length, the weight of a seed, and pulp weight. Analysis of variance components shows that the variability of Prosopis is generally greater among individuals than within vegetation types and climatic zones. Discriminant analysis showed that of the 19 morphometric characters seven (7) in the vegetation types and twelve (12) in climate zones revealed a statistically significant discriminating pattern $r$ (prob. <0.0001). From ascending cluster of 481 P. africana trees measured, 10 morphogroups were depicted on the basis of 19 morphometric characteristics $\left(R^{2}=52.6 \%\right)$.

\section{Keywords}

Morphological Variability, Climate Zone, Prosopis africana, Benin, West Africa

\footnotetext{
*Corresponding author.
}

How to cite this paper: Houètchégnon, T., Charlemagne, G.D.S.J., Christine, O. and Nestor, S. (2015) Morphological Variability of Prosopis africana (Guill., Perrott. Et Rich.) Taub in Benin, West Africa. American Journal of Plant Sciences, 6, 1069-1079. http://dx.doi.org/10.4236/ajps.2015.67111 


\section{Introduction}

Africa is a hotspot of wild and domesticated species with high agricultural and commercial potentiality. Yet, some of them still remain underutilized due to political and scientific reasons. The majority of these species are under high pressure due to human activities and demography matter [1]. One of the drawbacks upraised from ecosystems degradation during these last decades was the loss of natural regenerations for many species [2]. Drastic decline in crops production and loss of genetic diversity are the real risks to be observed in the long term. To mitigate these risks, it's urgent to set policies for protecting, domesticating, extending and valorizing potential species for the sake of local populations. Domestication process is always based on the selection of desirable genes, taking into account indigenous knowledge about target species [3]. Many studies had already concerned the variability of species showing great interest to the local populations. Among studies concerning morphological variability of species, one can underline those of [4] on Adansonia digitata in Mali, [5] on Argania spinosa in the South-West Morocco, [6] on Adansonia digitata in Benin, [7] and [8] on Sclerocarya birrea in Benin and in Burkina Faso, and [9] on Milicia excelsa. Some studies related to morphologic variability of Prosopis species were carried out by selected authors such as [10] on Prosopis juliflora and Prosopis pallida, of [11] and of [12]. However, none of those studies dealt with bearing and architectural parameters as well as production parameters such as the diameter, height, the number of primary branches, the length of pods, diameter and weight of pods, the weight of seeds, the weight of pulps, and the number of seeds per pod [13]-[15]. Globally, very few information had concerned the morphological variability and genetic diversity of $P$. africana according to agro-climatic gradients [16]. These parameters are necessary to be collected for studying the possibility of the species domestication. This was the case in Mali where the characterization of Phoenix dactylifera allowed scientists to select varieties of fruits with a big size, an appreciable height and an important rate of pulps for the date palm industries. Besides, [17] highlighted the morphology of Tamarindus indica seeds and discriminated varieties from West Africa, East Africa and Asia. Important morphological variability was also observed from Triticum monococcum for all the studied phenotypes and habitats for genes selection [18]. Based on the assumption that morphological variability of species depended on the diversity of its environmental area, this study collected data on Prosopis africana natural habitats in Benin. According to [19], morphological characterization could allow understanding morphological parameters of species and parameters related to environment. The study objectives were to i) determine the different morphometric characters of $P$. africana and describe their characteristics, ii) analyze the potential of morphometric parameters identified, and iii) analyze variations of morphometric characteristic according to climatic zones and vegetation types.

\section{Material and Methods}

\subsection{Study Area}

This study was carried out in the Republic of Benin located in West Africa between $1^{\circ}$ and $3^{\circ} 40^{\prime} \mathrm{E}$ and $06^{\circ} 30^{\prime}$ and $12^{\circ} 30^{\prime} \mathrm{N}$. It is bordered by Niger in the north, Burkina Faso in the northwest, Togo in the west, Nigeria in the east and the Atlantic Ocean in the south and covers an area of 112,622 $\mathrm{km}^{2}$ (Figure 1).

Benin is located in the Dahomey gap which is characterized by numerous physical constraints. The mean annual rainfall is low $(900-1300 \mathrm{~mm})$ compared with neighbouring countries in the Guineo-Congolean zone such as Ghana and Côte d'Ivoire (average of $1500 \mathrm{~mm}$ ) and Cameroon $(1800-3000 \mathrm{~mm})$.

[20] distinguished four major types of vegetation in Benin which are described as follows:

The coastal and sub-coastal zone, which extends from the coast $\left(6^{\circ} 20^{\prime} \mathrm{N}\right.$ up to $\left.7^{\circ} \mathrm{N}\right)$, is composed of beach vegetation with an abundance of Remirea maritima and Ipomea pescaprae, anthropic vegetation of mangrove swamp forests characterized by Rhizophora racemosa, Avicennia germinans and Dalbergia ecastaphylum, riparian forests, oil palm and coconut plantations. This zone has a subequatorial climate type with two rainy seasons (from mid-March to mid-July and from mid-September to mid-November) which alternate with two dry seasons (from mid-July to mid-September and from mid-November to mid-March).

The Guineo-Congolean zone composed of relict semi-deciduous forests characterized by species, such as $D i$ alium guineense, Triplochiton scleroxylon, Strombosia glaucescens, Cleistopholis patens, Ficus mucuso, Cola cordifolia, Ceiba pentandra, Trilepisium madagascariense, Celtis spp, Albizia spp, Antiaris toxicaria, Diopyros mespiliformis, Drypetes floribunda, Memecylon afzelii, Celtis brownii, Mimusops andogensis, Daniellia oliveri, Parkia spp and Vitellaria paradoxa [21]-[23] some savanna and plantation areas.

The Guineo-Sudanian Transition zone with a mosaic of forest woodlands, sometimes dry forests and wooded savanna crossed by gallery forests. The most abundant species found in this zone are Isoberlinia doka, I. tomen- 


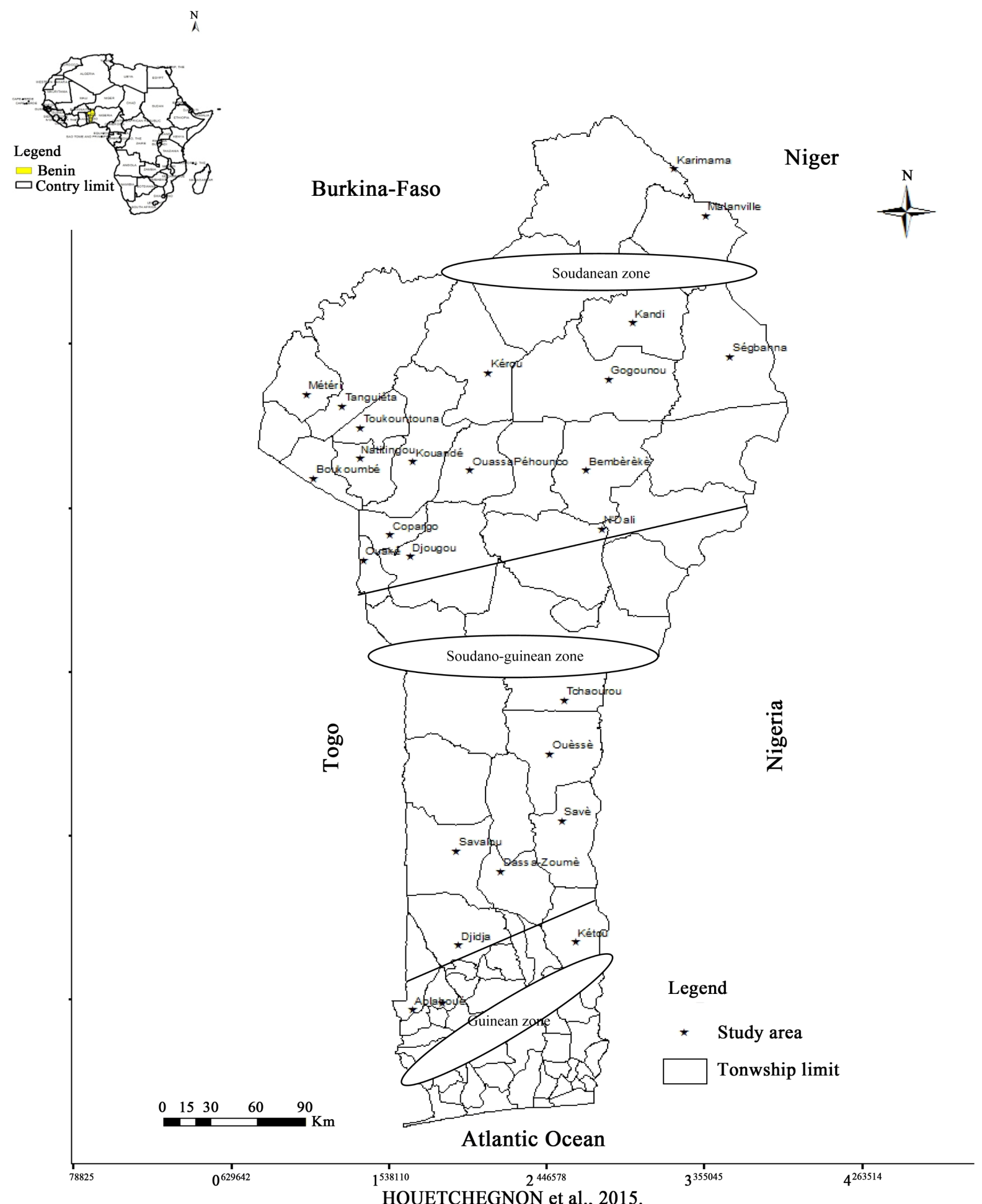

Laboratoire d'Etudes et de Recherches Forestières/Faculté d'Agronomie/Université de Parakou

Figure 1. Map showing zones of study.

tosa, Monotes kerstingii, Uapaca togoensis, Anogeissus leiocarpa, Antiaris toxicaria, Ceiba pentandra, Blighia sapida, Dialium guineense, Combretum fragrans, Entada africana, Maranthes polyandra, Pterocarpus erinaceus, Terminalia laxiflora and Detarium microcarpum. 
These two zones are characterized by a Guinean climate type with two rainy seasons and two dry seasons distributed as above but the short rainy season of this region is sometimes absent. The total annual rainfall reaches $1100 \mathrm{~mm}$.

The Sudanian zone composed of dry forests, savanna woodlands, shrub savanna and savanna grassland. The gallery forests are characterized by species, such as Haematostaphis barteri, Lannea spp, Khaya senegalensis, Anogeissus leiocarpa, Tamarindus indica, Capparis spinosa, Ziziphus mucronata, Combretum spp and Cissus quadrangularis. This zone has a Sudanian climate type with one rainy season (from April to October) followed by one dry season (from November to March). The average rainfall varies from $1100 \mathrm{~mm}$ in the southern part of this zone to $900 \mathrm{~mm}$ in the northern part.

According to the FAO world classification of soils, the major types of soil distinguished in Benin are: Leptosols in the coastal zone, Acrisols, Ferralsols or Lixisols and Vertisols in the Guineo-Congolean zone, Luvisols, Lixisols, Alisols, Plinthosols and Arenosols in the Sudano-Guinean transition and the Sudanian zones. Human pressure on land for agricultural purposes and forest exploitation is considerable. In southern Benin where population density varies from 200 to 450 inhabitants $/ \mathrm{km}^{2}$, average farmland area is 0.5 ha and the fallow system is more or less absent. In the north, where mean population density is 14 inhabitants per $\mathrm{km}^{2}$, average farmland area is 5 ha and fallow length is about 5 years. P. africana became rare in these fallows according to Maydell [24] by forest over-exploitation has led to declines in the number of some trees species per hectare.

\subsection{Material}

The species used in this study was Prosopis africana from Africa and belonging to the family group of Leguminoseae [25]. The main organs of Prosopis africana studied the pods, leaves and trunk. As for the measurable data, the decameter and machetes were used to shape and set plots. The Diameter at the breast height (DBH) was measured using $\pi$-tape. The SUNNTO compass was used to measure trees height and diameters of pods and seeds. The length of leaflets, pods and seeds were measure using calipers. The GPS was used to record geographical positions of study sites. The electronic balance was used to weigh pods, pulps and seeds.

\subsection{Data Collection}

To determine the morphological variability of Prosopis africana according to climatic zones (Guinean zones, Soudano-Guinean and Sudanese), forest inventory was carried out in three different vegetation types (savannah, fallowlands and farms). A number of 139 circular plots with $1000 \mathrm{~m}^{2}$ size were installed (39 in the Guinean zone, 46 in the Sudano-Guinean zone and 54 in the Sudanan zone). In each climatic zone, 40 plots were set in farms, 47 in the fallows and 52 in the savannah. Data recorded within each plot are the diameter at breast height $(\mathrm{DBH})$, the bole height, crown height, the crown diameter, number of branches from each individual tree. In these plots, 143 individuals were sampled to determine the length of leaf, the pinna length, leaf length, number of leaf, the number of leaflets, the stalk diameter and 735 fruits were sampled to determine the fruit pods diameter (clove), pod length, the total fruit weight and number of seeds per fruit, the seed length, the weight of seeds, pulp weight.

\subsection{Data Analysis}

Principal component analysis with 19 morphometric variables was performed to determine the morphological characters. This analysis allowed identifying characters with high variability. Besides, the Discriminant analysis was performed to test whether all the 19 morphometric variables could significantly discriminate groups such as climatic zones, localities, departments, vegetation and the species individuals. This analysis allowed identifying the main Discriminant variables. Ordination analysis was then used to classify variables using the coefficient of determination $\left(\mathrm{R}^{2}\right)$ with a threshold of 50\% [26]. Factorial analysis was afterward performed to analyze morphometric characteristics of the main Discriminant variables. Analysis was performed using the software SAS v9.2.

\section{Results}

\subsection{Variation of $P$. africana Morphometric Characteristics According to Climatic Zones, Localities of Study, Vegetation, Individuals of $P$. africana and Department}

Analysis of variance components showed that the variability of mesquite african (Prosopis africana) is generally 
greater within individual (error, Table 1). The change from one climatic zone to another observed is lower. Greater variability $(22 \%)$ between climatic zones is observed Lfolu. It is clear from these results that the greater variability of mesquite african is observed between the mesquite african tree and not between the vegetation or between locations or between municipalities or between departments and even less between climate zones. Diameter at breast height of Man, the height of the barrel, the height to first branch, the crown diameter, leaflet length and number of pinna and the number of leaflets, seeds and then the pod diameter have greater variability within localities while other variables: the length of leaf, petiole diameter, pod length and number of branches have their largest variability within plant communities. So there is a great heterogeneity in the mesquite same climate zone, Town, City, locality and plant formation. It is clear from this analysis that the classification of mesquite african tree (P. africana) is preferable to the classification of climatic zones, departments, municipalities, towns and plant formations from the mesquite african.

\subsection{The Discriminative Power Analysis of Morphometric Parameters Studied}

A good characterization of mesquite african tree according to vegetation or climate zones from or even classes mesquite african tree requires prior identification of the most discriminating morphometric characteristics. The results of stepwise discriminant analysis (Table 2) made for this purpose showed that seven of the 19 morphometric characters (7) in the vegetation and twelve (12) in climatic zones statistically significant discriminating power (prob. <0.0001). In other words, the classification of mesquite african tree as well as the analysis of the variation in morphometric characters following classes of mesquite african tree, the vegetation and climatic zones require consideration of 7 and 12 respectively for the vegetation variables and climatic zones.

The results also indicate that for discriminating feet mesquite plant formations, 7 the most discriminating morphometric characters are leaf length, diameter at breast height, the crown height, pod length, number of leaflets, the number of branches and petiole diameter. On the scale of climatic zones, the 12 most discriminating morphometric characters are the height crown, the pinna length, leaflet length, total weight fruit, the height to the first branch, the number of seeds, weight pulp, the number of leaflets, the diameter at breast height, height was, petiole diameter and number of branches.

Table 1. Principal components on P. africana morphological characteristics.

\begin{tabular}{|c|c|c|c|c|c|c|c|c|c|c|c|c|c|c|c|c|c|c|c|}
\hline $\begin{array}{l}\text { Components } \\
\text { of variance }\end{array}$ & $\mathrm{dbh}$ & Hf & $\mathrm{Hh}$ & $\mathrm{dh}$ & $\mathrm{Hr}$ & $\mathrm{nr}$ & $\mathrm{Lf}$ & Lfolu & Lfolio & Nfoli & Nfolu & Dpetio & Lgo & Dgou & PT & Ppu & Pgr & Lgra & Ngr \\
\hline \multirow[t]{2}{*}{$\mathrm{ZC}$} & 29.3 & 0.2 & 0.2 & 0.4 & 0.1 & 0 & 1.5 & 1.1 & 0.6 & 0.2 & 0 & 0.1 & 0.3 & 0.3 & 0 & 0 & 0 & 0 & 0.9 \\
\hline & $(6 \%)^{*}$ & $(3 \%)^{*}$ & $(1 \%) n$ & $(2 \%) n$ & $(2 \%)^{*}$ & $(0 \%) \mathrm{n}$ & $(5 \%) \mathrm{n}$ & $(22 \%)^{*}$ & $\begin{array}{c}(8 \%) \\
n\end{array}$ & $\begin{array}{c}(2 \%) \\
n\end{array}$ & $\begin{array}{c}(0 \%) \\
n\end{array}$ & $(2 \%) n$ & $(3 \%)^{*}$ & $(2 \%) n$ & $(0 \%) \mathrm{n}$ & $(0 \%) n$ & $(0 \%) \mathrm{n}$ & $\begin{array}{c}(0 \%) \\
n\end{array}$ & $(3 \%) n$ \\
\hline Dep (ZC) & 106.6 & 1.6 & 3.5 & 2.2 & 1 & 0.8 & 3.8 & 0.1 & 0.2 & 0.2 & 0.2 & 0 & 0.3 & 0.6 & 0 & 0 & 0 & 0 & 0.6 \\
\hline \multirow[t]{2}{*}{$\begin{array}{l}\text { Commune } \\
\text { (ZC }{ }^{*} \text { Dep) }\end{array}$} & 77.1 & 0.7 & 3.4 & 3 & 0.1 & 0.5 & 1.3 & 0.6 & 2.3 & 0.2 & 2.5 & 0.1 & 0.3 & 3.2 & 0 & 0 & 0 & 0.1 & 1.1 \\
\hline & $\begin{array}{c}(15 \%) \\
\text { ns }\end{array}$ & $(12 \%) \mathrm{n}$ & $(12 \%) n$ & $(16 \%) n$ & $(3 \%) n$ & $(9 \%) n$ & $(5 \%) n$ & $\begin{array}{c}(12 \%) \\
n\end{array}$ & $\begin{array}{c}(30 \%) \\
n\end{array}$ & $(2 \%)$ & $\begin{array}{c}(23 \%) \\
n\end{array}$ & $(2 \%) n$ & $(3 \%) n$ & $(23 \%)^{* * * *}$ & $*(0 \%) n$ & $(0 \%) \mathrm{n}$ & $(0 \%) \mathrm{n}$ & $\begin{array}{c}(14 \%) \\
n\end{array}$ & $(4 \%) n$ \\
\hline \multirow[t]{2}{*}{$\begin{array}{l}\text { Loca }\left(\mathrm{ZC}^{*}\right. \\
\left.\text { Dep }^{*} \text { Com }\right)\end{array}$} & 123.1 & 2.7 & 13.6 & 4.8 & 1.8 & 0.5 & 5.7 & 0 & 2.7 & 2.3 & 4 & 0 & 0.5 & 3.3 & 0 & 0 & 0 & 0 & 1.4 \\
\hline & $\begin{array}{c}(24 \%) \\
\text { ns }\end{array}$ & $(43 \%) n$ & $(47 \%) n$ & $(27 \%) n$ & $(60 \%) n$ & $(9 \%) \mathrm{n}$ & $(21 \%) n$ & $\begin{array}{c}(0 \%) \\
n\end{array}$ & $\begin{array}{c}(35 \%) \\
n\end{array}$ & $\begin{array}{c}(21 \%) \\
n\end{array}$ & $\begin{array}{c}(37 \%) \\
n\end{array}$ & $(0 \%) n$ & $(6 \%) n$ & $(24 \%) n$ & $(0 \%) n$ & $(0 \%) n$ & $(0 \%) \mathrm{n}$ & $\begin{array}{c}(0 \%) \\
n\end{array}$ & $(5 \%)$ \\
\hline \multirow[t]{2}{*}{$\begin{array}{c}\mathrm{FV} \\
\text { (ZC }^{*} \text { Dep } \\
\text { Com }{ }^{*} \text { Loca) }\end{array}$} & 63.1 & 0.4 & 2.8 & 2.8 & 0 & 2.4 & 14 & 0.1 & 0.8 & 2.2 & 0.5 & 0.1 & 0.7 & 1.7 & 0 & 0 & 0 & 0.1 & 3.9 \\
\hline & $(12 \%)^{* * *}$ & ${ }^{*}(7 \%)^{* * *}$ & $(10 \%)^{* * * *}($ & $(15 \%)^{* * *}$ & ${ }^{*}(0 \%)^{* * *}$ & $(46 \%)^{* * *}$ & $(51 \%)^{* * * *}$ & $\begin{array}{c}(2 \%) \\
n\end{array}$ & $(11 \%)^{* * *}$ & $\begin{array}{c}(20 \%) \\
n\end{array}$ & $\begin{array}{c}(4 \%) \\
n\end{array}$ & $(5 \%)^{* * *}$ & $(9 \%)^{* * * *}$ & $(12 \%)^{* * * *}$ & $(0 \%)^{* * *}$ & $(0 \%)^{* * * *}$ & $(0 \%)^{* * *}$ & $\begin{array}{c}(14 \%) \\
n\end{array}$ & $(13 \%)^{* * *}$ \\
\hline \multirow[t]{2}{*}{ Erreur } & 112.3 & 0.4 & 5.4 & 4.9 & 0 & 1 & 1.2 & 3.1 & 1.1 & 5.7 & 3.8 & 2.9 & 6.6 & 4.9 & 0.3 & 0.1 & 0.1 & 0.6 & 22.1 \\
\hline & $22 \%$ & $7 \%$ & $19 \%$ & $27 \%$ & $0 \%$ & $19 \%$ & $4 \%$ & $59 \%$ & $14 \%$ & $52 \%$ & $35 \%$ & $91 \%$ & $76 \%$ & $35 \%$ & $100 \%$ & $100 \%$ & $100 \%$ & $74 \%$ & $74 \%$ \\
\hline
\end{tabular}

ns $=$ non significative; ${ }^{*}$ significative at $5 \% ;{ }^{* * *}$ significative at $0.1 \%$. Legend: Variables: dbh: diameter at breast height; Hf: bole height; Hh: bunch height; dh: bunch diameter; hr: height at the first branche; nr: number of branche; LF: length of leaves; Lfolu: length of leaf; Lfolio: length of leaflets; Nfolio: number of leaf; Nfolu: number of leaflets; Dpetio: stalk diameter; Lgo: length of pod; Dgou: Diameter of pods; PT: total weight of fruit; Ngr: number of seed per pod; Pgr: weight of one seed; Ppu: weight of one pulp; ZC: zone climatic; Dep: department; com: commune; Loca: locality; FV: vegetation. 
Table 2. Discriminant power of morphometric characteristics of individuals according to climatic zones and vegetation.

\begin{tabular}{|c|c|c|c|c|c|c|c|c|c|}
\hline \multicolumn{6}{|c|}{ Discrimination of climatic zones } & \multicolumn{4}{|c|}{ Discrimination of vegetation } \\
\hline No. & Variables & F-Value & Wilks' $\Lambda$ & ASCC & No. & Variables & F-Value & Wilks' $\Lambda$ & ASCC \\
\hline 1 & $\mathrm{Hh}$ & $51.91^{* * *}$ & $0.59^{* * *}$ & $0.21^{* * *}$ & 1 & Lf & $45.40^{* * *}$ & $0.62^{* * *}$ & $0.19^{* * *}$ \\
\hline 2 & Lfolu & $29.17^{* * *}$ & $0.42^{* * *}$ & $0.34^{* * *}$ & 2 & $\mathrm{dbh}$ & $15.92^{* * *}$ & $0.51^{* * *}$ & $0.27^{* * *}$ \\
\hline 3 & Lfolio & $20.16^{* * *}$ & $0.33^{* * *}$ & $0.40^{* * *}$ & 3 & $\mathrm{Hh}$ & $15.60^{* * *}$ & $0.42^{* * *}$ & $0.33^{* * *}$ \\
\hline 4 & PT & $17.07^{* * *}$ & $0.27^{* * *}$ & $0.45^{* * *}$ & 4 & Lgousse & $6.85^{*}$ & $0.39^{* * *}$ & $0.35^{* * *}$ \\
\hline 5 & $\mathrm{hr}$ & $12.93^{* * *}$ & $0.23^{* * *}$ & $0.49^{* * * *}$ & 5 & Nfolu & $3.26^{*}$ & $0.37^{* * *}$ & $0.36^{* * *}$ \\
\hline 6 & Ngrai & $6.85^{* * *}$ & $0.21^{* * *}$ & $0.51^{* * *}$ & 6 & $\mathrm{nr}$ & $2.77 \mathrm{n}$ & $0.36^{* * *}$ & $0.38^{* * *}$ \\
\hline 7 & Ppulpe & $10.95^{* * *}$ & $0.18^{* * *}$ & $0.53^{* * *}$ & 7 & Dpetiole & $3.33^{*}$ & $0.34^{* * *}$ & $0.39^{* * *}$ \\
\hline 8 & Nfolu & $4.06^{*}$ & $0.17^{* * *}$ & $0.54^{* * *}$ & & & & & \\
\hline 9 & dbh & $3.16^{*}$ & $0.16^{* * *}$ & $0.55^{* * *}$ & & & & & \\
\hline 10 & $\mathrm{Hf}$ & $3.55^{*}$ & $0.16^{* * *}$ & $0.56^{* * *}$ & & & & & \\
\hline 11 & Dpetiole & $3.94^{*}$ & $0.15^{* * *}$ & $0.58^{* * *}$ & & & & & \\
\hline 12 & $\mathrm{nr}$ & $4.63^{*}$ & $0.14^{* * *}$ & $0.60^{* * *}$ & & & & & \\
\hline
\end{tabular}

ASCC $=$ Average Squared Correlation Canonical; ${ }^{* * *}$ Significant at $1 \% 0 ;{ }^{*}$ significant at $0.5 \% ; \mathrm{n}=$ non significant. Variables: dbh: diameter at breast height; Hf: bole height; Hh: bunch height; dh: bunch diameter; hr: height at the first branche; nr: number of branche; LF: length of leaves; Lfolu: length of leaf; Lfolio: length of leaflets; Nfolio: number of leaf; Nfolu: number of leaflets; Dpetiol: stalk diameter; Lgousse: length of pod; Dgouss: Diameter of pods; PT: total weight of fruit; Ngrai: number of seed per pod; Pgrai: weight of one seed; Ppulp: weight of one pulp.

\subsection{Grouping of Mesquite african Tree Classes}

The ascending hierarchical classification of 481 mesquite african tree measured on the basis of 19 morphometric characteristics identified 10 classes of mesquite african tree with a coefficient of determination $\left(\mathrm{R}^{2}\right)$ of $52.6 \%$ (see Figure 2). $\mathrm{R}^{2}$ carry value is enough to obtain sufficiently different classes from each other. Classes $\mathrm{C} 2, \mathrm{C} 1$ and $\mathrm{C} 3$ are the richest in terms of number of mesquite african tree while $\mathrm{C} 9$ and $\mathrm{C} 10$ classes contain fewer individuals measured (Figure 3).

Analysis of classes showed (Table 3) that classes 5, 7, 9 and 10 are those containing individuals from the Guinean zone; classes 6 and 8 are those individuals from the Sudano-guinean zone and classes 2 and 3 contain individuals from the three climatic zones. Considering vegetation, classes 1, 2, 3, 4 and 6 contains individuals from the three type of vegetation (fallow, farm and savannah). The class 7 contains individuals from the farm and savannah whereas classes 5,8,9 and 10 contain individuals only from fallows.

\subsection{Morphometric Characteristics of $P$. africana}

Results from the factorial analysis showed a significant different among classes (Wilks' Lambda $=0.0114 ; \mathrm{p}<$ 0.0001) (Table 4). The results (Table 5) showed that the first four axes explained $84.43 \%$ of information related to classes. Variable such as the length of leaves, leaf and leaflets, the number of leaflets, individuals, the weight and number of seeds are positively correlated with the axis 1 . This axis indicates the characteristics of leaves. Variables such as length and diameter of pods are positively correlated with axis 2 . This axis indicates the characteristics of fruits (pods). The axis is positively correlated with dendrometric parameters such as diameters and height.

Table 6 shows the means and coefficient of variation of the 19 Morphometric parameters according to the climatic zones. Values of the means allowed appreciating the heterogeneity of the climatic zone. Results shows that highest values of DBH $(40.8 \mathrm{~m} \pm 42.1 \%)$, bole height $(4.6 \mathrm{~m} \pm 48.3 \%)$, number and length $(10.7 \mathrm{~cm} \pm$ $32.4 \%)$ of leave, stalk diameter $(15.4 \mathrm{~mm} \pm 9.4 \%)$, number of seeds $(14 \% \pm 43 \%)$, weight of seeds $(0.3 \mathrm{~g} \pm$ $45 \%)$, pods and pulps $(3.9 \% \pm 50.4 \%$.), number of branches $(4.6 \pm 68.8)$ are observed from the Guinean zone whereas the highest values of pods diameters $(7.6 \mathrm{~mm} \pm 126.4 \%)$ and length $(19.3 \mathrm{~cm} \pm 17.9 \%)$, length of leaflets $(8.2 \mathrm{~cm} \pm 18.9)$ were observed from the remaining two zones. 


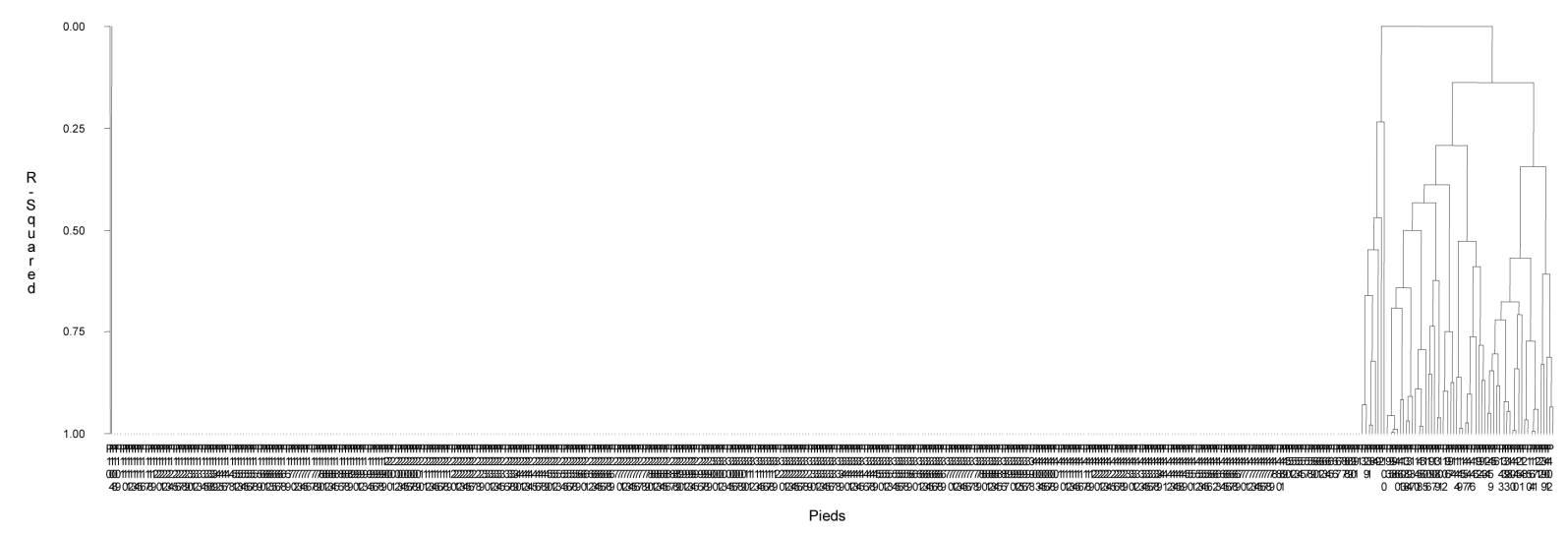

Figure 2. Cluster of individuals.

Table 3. Climatic zone and vegetation level according to classes.

\begin{tabular}{|c|c|c|c|c|c|c|c|c|c|c|}
\hline & $\mathrm{C} 1$ & $\mathrm{C} 2$ & $\mathrm{C} 3$ & $\mathrm{C} 4$ & $\mathrm{C} 5$ & $\mathrm{C} 6$ & $\mathrm{C} 7$ & $\mathrm{C} 8$ & C9 & $\mathrm{C} 10$ \\
\hline \multicolumn{11}{|c|}{ Climatic zones } \\
\hline G & 0 & 0.47 & 0.30 & 0.50 & 1 & 0 & 1 & 0 & 1 & 1 \\
\hline SG & 0.67 & 0.41 & 0.40 & 0.50 & 0 & 1 & 0 & 1 & 0 & 0 \\
\hline $\mathrm{S}$ & 0.33 & 0.12 & 0.30 & 0 & 0 & 0 & 0 & 0 & 0 & 0 \\
\hline \multicolumn{11}{|c|}{ Vegetal formation } \\
\hline $\mathrm{C}$ & 0.22 & 0.47 & 0.10 & 0.25 & 0 & 0.20 & 0.4 & 0 & 0 & 0 \\
\hline $\mathrm{J}$ & 0.33 & 0.12 & 0.20 & 0.25 & 1 & 0.60 & 0 & 1 & 1 & 1 \\
\hline $\mathrm{Sa}$ & 0.44 & 0.41 & 0.70 & 0.50 & 0 & 0.20 & 0.6 & 0 & 0 & 0 \\
\hline
\end{tabular}

Legend: G: Guinean zone; SG: Sudano-guinean; S: Sudanian zone; C: Farm J: Fallow; Sa: Savannah.

Table 4. Positioning of each class on each axis.

\begin{tabular}{cccc}
\hline Classe & Can 1 & Can 2 & Can 3 \\
C1 & 0.726 & -0.953 & -0.358 \\
C2 & 0.765 & 0.035 & $\mathbf{1 . 5 9 7}$ \\
C3 & -0.435 & $\mathbf{1 . 9 8 1}$ & -0.478 \\
C4 & $\mathbf{- 2 . 0 4 2}$ & $\mathbf{5 . 6 0 9}$ & 0.612 \\
C5 & $\mathbf{3 . 1 6 0}$ & -1.025 & -0.558 \\
C6 & 1.280 & -0.150 & $-\mathbf{2 . 1 8 2}$ \\
C7 & $\mathbf{- 2 . 6 9 3}$ & $-\mathbf{1 . 9 6 4}$ & 0.412 \\
C8 & $\mathbf{- 3 . 7 7 6}$ & -0.718 & -0.614 \\
C9 & $\mathbf{- 4 . 1 0 4}$ & -0.989 & $-\mathbf{0 . 8 9 6}$ \\
C10 & 1.084 & 0.326 & -0.688 \\
m & $\mathbf{2 . 0 0 1}$ & $\mathbf{1 . 3 7 5}$ & $\mathbf{0 . 8 4 0}$ \\
e & $\mathbf{0 . 4 2 6}$ & $\mathbf{0 . 5 1 6}$ & $\mathbf{0 . 1 8 6}$ \\
\hline
\end{tabular}




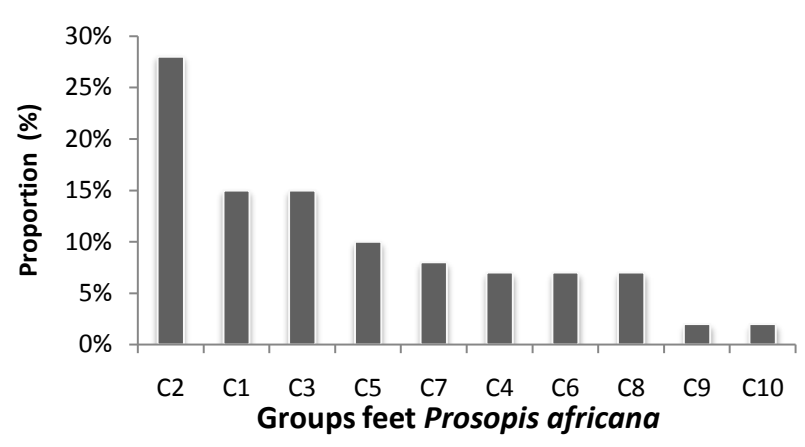

Figure 3. Weight of each class of prosopis.

Table 5. Correlation between variables and axes.

\begin{tabular}{ccccc}
\hline Variable & Can 1 & Can 2 & Can 3 & Can 4 \\
\hline DBH & -0.053 & 0.188 & 0.036 & $\mathbf{0 . 6 5 0}$ \\
Bole height & 0.085 & 0.249 & -0.153 & $\mathbf{0 . 7 2 9}$ \\
Bunch height & 0.383 & 0.064 & -0.293 & $\mathbf{0 . 5 9 5}$ \\
Bunch diameter & 0.216 & 0.134 & 0.410 & 0.195 \\
Height at first branche & -0.038 & 0.276 & 0.322 & $\mathbf{0 . 5 7 2}$ \\
Number of branche & -0.080 & -0.242 & $-\mathbf{0 . 7 0 3}$ & 0.445 \\
Length of leaves & $\mathbf{0 . 6 9 7}$ & -0.129 & -0.003 & 0.407 \\
Length of leaflet & -0.055 & 0.173 & 0.021 & -0.105 \\
Length of leaf & $\mathbf{0 . 5 8 6}$ & 0.196 & 0.049 & 0.274 \\
Number of leaf & $\mathbf{0 . 7 2 2}$ & -0.028 & -0.053 & 0.142 \\
Number of leaflet & 0.299 & -0.068 & 0.013 & 0.100 \\
N individual & $\mathbf{0 . 5 8 5}$ & -0.180 & -0.157 & 0.112 \\
Stalk diameter & -0.313 & 0.108 & 0.281 & 0.403 \\
Length of pods & -0.161 & $\mathbf{0 . 6 0 9}$ & -0.246 & -0.481 \\
Diameter of pods & -0.239 & $\mathbf{0 . 5 5 9}$ & 0.061 & -0.282 \\
Total height of fruit & -0.400 & -0.092 & 0.388 & 0.211 \\
Number of seeds & $-\mathbf{0 . 4 9 4}$ & 0.186 & 0.456 & 0.202 \\
Seeds weight & $-\mathbf{0 . 6 9 1}$ & 0.295 & 0.178 & -0.063 \\
Pulps weight & -0.421 & -0.250 & 0.141 & 0.095 \\
\hline
\end{tabular}

Table 6. Variation of the 19 morphometric parameters according to climatic zones: mean $(\mathrm{m})$ and coefficient of variation $(\mathrm{Cv}, \%)$.

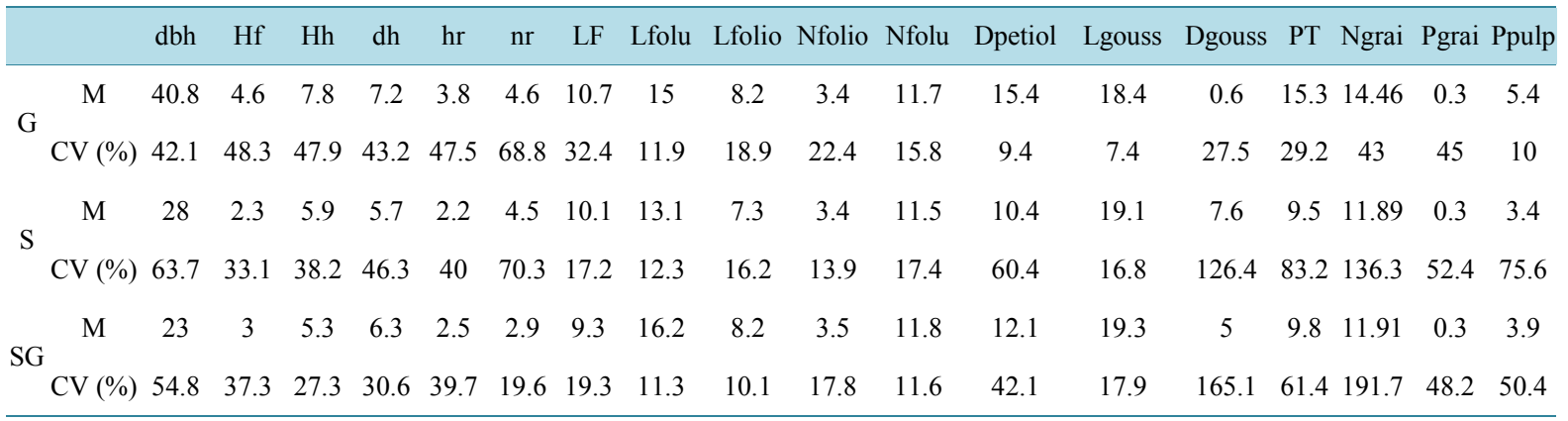

Variables: dbh: diameter at breast height; Hf: bole height; Hh: bunch height; dh: bunch diamleter; hr: height at the first branche; nr: number of branche; LF: length of leaves; Lfolu: length of leaf; Lfolio: length of leaflets; Nfolio: number of leaf; Nfolu: number of leaflets; Dpetiol: stalk diameter; Lgouss: length of pod; Dgouss: diameter of pods; PT: total weight of fruit; Ngrai: number of seed per pod; Pgrai: weight of one seed; Ppulp: weight of one pulp. 


\section{Discussion}

\subsection{Environmental Impacts on Morphological Characteristics of Prosopis}

Results from the Discriminant Analysis revealed that 12 of the 19 morphometric parameters significantly discriminate the climatic zones and 7 of them discriminate the vegetation. Variables such as DBH, bole height, diameter of and numbers leaflets, the number of seeds and the diameters of pods are highly important in localities from different climatic zones whereas variable such as number of branches, length of leaves, diameter of stalk are highly important in the vegetation. These results are similar to those of [27]-[30] that showed the variation of Morphometric characters according to the environment and abiotic stresses. Climatic and soil factors determine the distribution and morphology of vegetation and animals [31].

\subsection{The Main Parameters for Accurate Tree Species Morphological Study}

Many authors [12] [24] [32] [33] used some parameters such as the total height, the length of leaves and leaflets, the number of seeds per pods and the length of pods to characterize Prosopis africana. The current study results showed that 12 morphometric parameters significantly discriminate the climatic zones and 7 discriminate the vegetation. Variables with high discriminative variance in the climatic zones are $\mathrm{DBH}$, bole height, diameter of and numbers leaflets, the number of seeds and the diameters of pods and those with high discriminative variance in the vegetation are number of branches, length of leaves, and diameter of stalk. These results are similar to those of [12] [24] [32] [33].

[9] revealed that the length of leaves characterizes the populations of Niaouli Iroko. According to [5] leaves can be used to characterize Argania spinosa. As for [34], the main parameters for describing Detarium microcarpum are the length and surface of leaflet, the size of the pulps, the length of fruits, seeds and endocarp. [6] showed that the most discriminative variables of baobab type of capsules in Benin are the length and number of seeds, the size and weight of pulps-seeds, the total weight of capsules and the ratio length/width of capsules. [4] in Burkina Faso indicated that the same Morphometric parameters underlined by [6] characterize with high variability baobab. As afr as Sclerocarya birrea is concerned, discriminative parameters are the diameter of fruits, the number of seeds, the seeds weight, the bole height and the number of primary branches [8]. [35] underlined that the individuals of Parkia biglobosa from Kalalé locality in Benin showed high means values of pods weight, the number of seeds per pods and the number of pods per infuriating and can be used for varieties selection.

\section{Conclusion}

The study about the morphological variability of $P$. africana allowed identifying 12 morphometric parameters significantly discriminating the climatic zones and 7 parameters discriminating the vegetation types. Variables with high discriminative variance in the climatic zones are $\mathrm{DBH}$, bole height, diameter and numbers of leaflets, the number of seeds, and the diameters of pods, and those with high discriminative variance in the vegetation are number of branches, length of leaves, and diameter of stalk. Analysis of the morphometric characteristics variation according to climatic zones showed that the length and weight of pod were highly important in the Guinean zone. Besides, the diameter at breast height and the length of leaf are also important in the Guinean zone. It would be interesting to consider Prosopis africana populations in the Guinean zone as part of a selection of high-yielding varieties.

\section{Acknowledgements}

We are grateful to the International Tropical Timber Organization for their financial support.

\section{References}

[1] Gebauer, J., El-Siddig, K. and Ebert, G. (2002) Baobab (Adansonia digitata L.). A Review on a Multipurpose Tree with Promising Future in the Sudan. Gartenbauwiss, 4,155-160.

[2] Gijsbers, H.J.M., Kessler, J.J. and Knevel, M.K. (1994) Dynamics and Natural Regeneration of Woody Species in Farmed Parklands in the Sahel Region (Province of Passore, Burkina Faso). Forest Ecology and Management, 64, 1-12. http://dx.doi.org/10.1016/0378-1127(94)90122-8

[3] Soloviev, P., Niang, T.D., Gaye, A. and Totte, A. (2004) Variabilité des caractères physico-chimiques des fruits de trois 
espèces ligneuses de cueillette, récoltés au Sénégal: Adansonia digitata, Balanites aegyptiaca et Tamarindus indica. Fruits, 59, 109-119. http://dx.doi.org/10.1051/fruits:2004011

[4] Kouyaté, A.M., Decaluwé, E., Guindo, F., Diawara, H., Diarra, I., N’Diayé, I. and Van Damme, P. (2011) Variabilité morphologique du baobab (Adansonia digitata L.) au Mali. Fruits, 66, 247-255. http://dx.doi.org/10.1051/fruits/2011032

[5] Zahidi, A., Bani-Aameur, F. and El Mousadik, A. (2013) Variability in Leaf Size and Shape in Three Natural Populations of Argania spinosa (L.) Skeels. International Journal of Current Research and Academic Review, 1, 13-25.

[6] Assogbadjo, A.E. (2006) Importance socio-économique et étude de la variabilité écologique, morphologique, génétique et biochimique du baobab (Adansonia digitata L.) au Bénin. Thèse de doctorat, Faculteit Bio-Ingenieurswetenschappen, Universiteit Gent, 213 p.

[7] Gouwakinnou, N.G. (2011) Population Ecology, Uses and Conservation of Sclerocarya birrea (A. Rich) Hocchst. (Anacardiaceae) in Benin, West Africa. Ph.D. Thesis, University of Abomey-Calavi, Abomey-Calavi, 176.

[8] BATIONO/KANDO, P., Zongo, J.D., Nanema, R.K. and Traore, E.R. (2008) Etude de la variation de quelques caractères morphologiques d'un échantillon de Sclerocarya birrea au Burkina Faso. International Journal of Biological and Chimical Sciences, 2, 549-562.

[9] Ouinsavi, C. and Sokpon, N. (2010) Morphological Variation and Ecological Structure of Iroko (Milicia excelsa Welw. C.C. Berg) Populations across Different Biogeographical Zones in Benin. International Journal of Forestry Research, 2010, Article ID: 658396, 10 p. http://dx.doi.org/10.1155/2010/658396

[10] Pasiecznik, N.M., Felker, P., Harris, P.J.C., Harsh, L.N., Cruz, G., Tewari, J.C., Cadoret, K. and Maldonado, L.J. (2001) The Prosopis juliflora-Prosopis pallida Complex: A Monograph. HDRA, Coventry, 172.

[11] Arbonnier, M. (2002) Arbres arbustes et lianes des zones sèches d'Afrique de l'Ouest. CIRAD-MNHN, 573 p.

[12] Vautier, H. and Sacandé, M. (2007) Seed Leaflet Prosopis africana (Guill. \& Perr.) Taub. Millennium Seed Bank Project, Wakehurst Place, Ardingly, No. 132. www.kew.org/msbp

[13] Leakey, R.R.B., Fondoum, J.M., Atangana, A. and Tchoundjeut, Z. (2000) Quantitative Descriptors of Variation in the Fruits and Seeds of Irvingia gabonensis. Agroforestry Systems, 50, 47-58. http://dx.doi.org/10.1023/A:1006434902691

[14] Leakey, R.R.B., Shckleton, S. and du Plessis, P. (2005) Domestication Potential of Marula (Sclerocarya birrea subsp caffra) in South Africa and Namibia: 1 Phenotypic Variation in Fruit Traits. Agroforestry Systems, 64, 25-35. http://dx.doi.org/10.1007/s10457-005-2419-z

[15] Leakey, R.R.B., Pate, K. and Lombard, C. (2005) Domestication Potential of Marula (Sclerocarya birrea subsp caffra) in South Africa and Namibia: 2 Phenotypic Variation in Nut and Kernel Traits. Agroforestry Systems, 64, 37-49. http://dx.doi.org/10.1007/s10457-005-2420-6

[16] Sidibé, M. and Williams, J.T. (2002) Baobab Adansonia Digitata. International Centre for Underutilised Crops, Southampton.

[17] Diallo, O.B. (2001) Biologie de reproduction et évaluation de la diversité génétique chez une légumineuse Tamarindus indica L. (Ceasalpinioideae). 119 Université de Montpellier II Sciences et Techniques du Languedoc.

[18] Empilli, S., Castagna, R. and Brandolini, A. (2000) Morpho-Agronomic Variability of the Diploid Wheat Triticum monococcum L. Plant Genetic Resources Newsletter, 36-40.

[19] Zhang, D. (2012) Marqueurs moléculaires. Outils de choix pour le génotypage des plantes. In: Les apports de la biologie moléculaire en arboriculture fruitière, 12e colloque sur les recherches fruitières, INRA, Bordeaux, 2002.

[20] Adjanohoun, E., Adjakidjè, V., Ahyi, M.R.A., Aké Assi, L., Akoègninou, A., Dalmeda, J., Akpovo, F., Boukef, K., Chadaré, F., Cusset, G., Dramane, K., Eyme, J., Gassita, J.N., Gbaguidi, N., Goudoté, E., Guinko, S., Houngnon, P., Issa, L., Keita, A., Kiniffo, H.V., Koné Bamba, D., Musampa Nseyya, A., Saadou, N., Sodogandji, T.H., De Souza, S., Tchabi, A., Zinsou Dossa, C. and Zohoun, Th. (1989) Contribution aux études ethnobotaniques et floristiques en République Populaire du Bénin. ACCT, Paris, 895 p.

[21] Sokpon, N. (1994) Tenure Foncière et Propriété des Ligneux Dans Les Systèmes Agroforestiers Traditionnels au Bénin. Annales de la Faculté des Sciences de Kisangani, Numéro Spécial, 115-122.

[22] Sokpon, N. and Lejoly, J. (1996) Les Plantes à Fruits Comestibles D’une Forêt Semi-Caducifoliée de Pobè au Sudest du Bénin. In: Hladik, C.M., Hladik, A., Pagezy, H., Linares, O.F. and Froment, A., Eds., L'alimentation en Forêt Tropicale: Interactions Bioculturelles et Perspectives de Développement, Vol. 1, UNESCO, Paris, 115-124.

[23] Ouinsavi, C. and Sokpon, N. (2008) Traditional Agroforestry Systems as Tools for Conservation of Genetic Ressources of Milicia excelsa Welw. C.C. Berg. in Benin. Agroforestry Systems, 74, 17-26. http://dx.doi.org/10.1007/s10457-008-9109-6

[24] Von Maydell, H.J. (1983) Arbres et arbustes du Sahel. Leurs caractéristiques et leurs utilisations. Gtz.385 p + annexes.

[25] Akinnagbe, A. and Oni, O. (2007) Quantitative Variations in the Growth of Progeny Seedlings of Prosopis africana 
(Guill., Perrott. and Rich.) Plus Trees in Nigeria. African Journal of Biotechnology, 6, 359-363.

[26] Glèlè Kakaï, R., Sodjinou, E. and Fonton, N. (2006) Conditions d'application des méthodes statistiques paramétriques: Application sur ordinateur. Bibliothèque Nationale, Bénin, $86 \mathrm{p}$.

[27] Fresnaye, J. (1981) Biométrie de l'abeille. Office pour l'Information et la Documentation en Apiculture, Echauffour (Orne), 54.

[28] Garnery, L. (1998) Genetic Diversity of the West European Honey Bee (Apis mellifera mellifera and A. $m$. berica). 1. Mitochondrial DNA. Genet. Sel. Evol., 30, 31-42.

[29] Toullec, A.N.K. (2008) Abeille noire, Apis mellifera mellifera. Historique et sauvegarde. Thèse de Doctorat Vétérinaire, Faculté de Médecine de Créteil, 168.

[30] Abiola, A.W. (2012) Caractérisation morphométrique de l'abeille Apis mellifera adansonii, latreille 1804 (hymenoptera: Apidae) au Bénin. Thèse d'Ingénieur Agronome, Faculté d'Agronomie, Université de Parakou, Benin, 71 p.

[31] White, F. (1986) La végétation de l'Afrique. Recherches sur les ressources naturelles XX, ORSTOM-UNESCO, Paris.

[32] Eyog Matig, O., Adjanohoun, E., de Souza, S. and Sinsin, B. (1999) Réseau "Espèces Ligneuses Médicinales" Compte rendu de la première réunion du réseau, 15-17 décembre 1999, Station IITA Cotonou, Bénin.

[33] Arbonnier, M. (2000) Arbres, arbustes et lianes des zones sèches de d'Afrique de l'Ouest. Ed.CIRAD-MNHN-UICN, $525 \mathrm{p}+$ annexes.

[34] Kouyaté, A.M. (2005) Aspects ethnobotaniques et étude de la variabilité morphologique, biochimique et phénologique de Detarium macrocarpum Guill. \& Perr. Au Mali. Thèse présentée pour l'obtention du grade de Doctorat $(\mathrm{PhD})$ en Biosciences Ingénieurs, section Agronomie, Université de Ghent, Belgique, 207.

[35] Koura, K., Mbaide, Y. and Ganglo, J.C. (2013) Caractéristiques phénotypique et structurale de la population de Parkia biglobosa (Jacq.) R. Br. du Nord-Bénin. International Journal of Biological and Chemical Sciences, 7, 2409-2425. 